\title{
MODEL KONSELING KELOMPOK UNTUK MENINGKATKAN SELF-EFFICACY MAHASISWA
}

\author{
Awaluddin Tjalla \& Herdi \\ e-mail: awaluddin.tjalla@gmail.com \\ Jurusan Bimbingan Konseling, FIP Universitas Negeri Jakarta
}

\begin{abstract}
Abstrak: Tujuan penelitian adalah menghasilkan model model konseling kelompok untuk meningkatkan self-efficacy mahasiswa Jurusan BK FIP UNJ yang sedang menulis skripsi angkatan 2007. Penelitian dilaksanakan di Jurusan BK FIP UNJ. Penelitian ini dilakukan di Jurusan BK FIP UNJ pada tahun akademik 2011/2012 Sampel penelitian adalah mahasiswa angkatan 2007 yang berjumlah 48 orang yang diambil menggunakan teknik simple random sampling. Penelitian menggunakan metode Research $\&$ Development (R \& D). Pengumpulan data menggunakan instrumen KKM calon konselor yang telah diuji validitas dan reliabilitasnya. Hasil penelitian dibagi menjadi dua bagian, pertama mahasiswa Jurusan BK FIP UNJ 2007 yang sedang menulis skripsi memiliki self-efficacy yang tinggi $52.1 \%$ dan sisanya rendah $47.9 \%$. Kedua, model konseling kelompok yang diprediksi efektif untuk meningkatkan self-efficacy adalah konseling kelompok kognitif-perilaku (KKKP). Model KKKP yang dihasilkan terdiri atas: rasional, tujuan, komponen utama, format, sesi, peran konselor, tahapan konseling, dan indikator keberhasilan. Rekomendasi penelitian ditujukan kepada civitas akademika Jurusan BK, mahasiswa dan peneliti selanjutnya untuk menguji efektivitas dan menggunakan model KKKP dalam meningkatkan self-efficacy mahasiswa.
\end{abstract}

Kata kunci: model, konseling kelompok, self-efficacy, mahasiswa

\section{GROUP COUNSELLING MODEL TO IMPROVE THE STUDENTS' ACADEMIC SELF-EFFICACY}

\begin{abstract}
Abstrak: This research aimed at producing a group counselling model to improve the students' self-efficacy at Gudance and Counselling Department of School of Education, State University of Jakarta. The students 2007 academic year were writing their thesis. Taking a place in Gudance and Counselling Department of School of Education, State University of Jakarta, the research was conducted in the academic year of 2011/2012. The sample of 48 students were selected by random sampling from the students registered ini 2007. The research and development method was employed and the data were collected using the instrument of Multicultural Counselling Competence for counsellor candidates, which had been validated and its realibility had been tested. The findings wre classified into two groups. The first indicated $52.1 \%$ of the students have high self-efficacy. The second, the predictive effective group counselling model predicted was behavior-cognitive group counselling. The prodused model consisted of rationale, objective, main componen, format, session, counsellor's roles, counselling phases, and success indicator. The research recommended Gudance and Counselling Department, students and researchers to do further research testing the effectivness of the model to improve students' self-efficacy.
\end{abstract}

Key words: model, group counselling, self-efficacy, behavior-cognitive group counselling.

\section{PENDAHULUAN}

Lulus atau tidaknya seorang mahasiswa dari suatu perguruan tinggi, termasuk Jurusan Bimbingan dan Konseling (BK) Fakultas Ilmu Pendidikan (FIP) Universitas Negeri Jakarta (UNJ) ditentukan oleh penyelesaian tugas akhir - salah satunya skripsi. Dalam proses pembimbingan skripsi, banyak mahasiswa yang lancar dalam menulis skripsinya, tetapi tidak sedikit pula yang mengalami hambatan, baik disebabkan oleh faktor internal maupun eksternal.
Di Jurusan BK FIP UNJ pada tahun akademik 2010/2011 tercatat mahasiswa angkatan 2007 yang berjumlah 120 orang mengontrak skripsi. Namun, pada masa ujian skripsi bulan Januari 2012 tahun akademik 2011/2012 tercatat hanya 20 orang mahasiswa yang mengikuti dan lulus ujian skripsi. Sisanya, yang berjumlah 100 orang masih dalam proses penulisan skripsi. Artinya, mahasiswa Jurusan BK FIP UNJ angktan 2007 telah menulis skripsi selama dua (2) semester dan memasuki semester ketiga. Dengan kata lain, mahasiswa angkatan 2007 mengalami hambatan 
dalam penulisan skripsi karena melebihi batas waktu penyelesaian skripsi yang ditetapkan di dalam Pedoman Penyelesaian Studi Mahasiswa FIP UNJ. Kondisi ini bertentangan dengan kebijakan FIP bahwa perpanjangan waktu penyelesaian skripsi maksimal satu semester atas usul pembimbing I dan II dan mendapat persetujuan Ketua Jurusan/Ketua Program Studi.

Hasil studi pendahuluan melalui wawancara tidak terstruktur dengan mahasiswa menunjukkan mereka yang lancar menyusun dan lulus ujian skripsi salah satunya didukung oleh keyakinan akan kemampuannya, ketekunan dan pantang menyerah dalam menulis skripsi. Sebaliknya, mahasiswa yang terhambat karena ketidakyakinan akan kemampuan diri, malas, dan mudah putus asa dalam menyusun, serta menyelesaikan dan mengikuti ujian skripsi.

Keyakinan individu terhadap kemampuannya dalam mengerjakan tugas atau mengatasi masalah yang dihadapinya disebut self-efficacy (Bandura, 1977; 1997; Maddux, 2005) atau academic self-efficacy (Zimmerman, 2000) terkait dengan keyakinan dalam mengerjakan tugas atau mengatasi masalah akademik. Academic self-efficacy didefinisikan sebagai personal judgements of one's capabilities to organize and execute courses of action to attain designated types of educational performances (Zimmerman, 2000). Self-efficacy mempengaruhi pilihan tugas, usaha, ketekunan, kegembiraan, prestasi atau kinerja mahasiswa. Mahasiswa dengan self-efficacy yang tinggi, cenderung akan menunjukkan partisipasi atau penyelesaian tugas-tugas yang lebih aktif dan siap, bertahan lebih lama ketika menghadapi kesulitan dan meraih prestasi yang lebih tinggi jika dibandingkan dengan mahasiswa yang meragukan kemampuannya.

Bandura (1977) mengembangkan skala selfefficacy untuk mengases dimensi magnitude atau level, generality, dan strength dalam berbagai aktivitas dan konteks kehidupan, termasuk aktivitas dan konteks pendidikan (akademik). Dimensi magnitude atau level mengukur tingkat keyakinan individu terhadap kemampuannya dalam menentukan tingkat kesulitan tugas atau masalah yang dihadapinya, misalnya mengatasi masalah atau kesulitan dalam matematika. Dimensi generality mengukur tingkat keyakinan individu terhadap kemampuannya dalam menggeneralisasikan keberhasilannya ketika mengatasi atau menyelesaikan masalah atau tugas-tugasnya, misalnya dalam mata pelajaran yang berbeda. Dimensi strength mengukur keyakinan individu terhadap kemampuannya dalam mengatasi masalah atau kesulitan yang muncul akibat tugas-tugasnya.

Jika permasalahan tersebut dibiarkan berlalu, berjalan begitu saja, dikhawatirkan dapat menimbulkan keterhambatan mahasiswa dalam penyelesaian studi, sehingga terjadinya kevakuman kreativitas dan produktivitas serta "kematian" iklim akademik mahasiswa, memperburuk citra dan menurunkan akreditasi BAN-PT Jurusan BK FIP UNJ, karena banyak mahasiswa yang tidak dapat menyelesaikan studi tepat waktu. Oleh karena itu, harus ada upaya nyata yang dilakukan secara sistematik, sistemik, terstruktur, simultan, dan komprehensif untuk memahami dan meningkatkan academic self-efficacy mahasiswa Jurusan BK FIP UNJ.

Salah satu upaya yang dapat dilakukan, yaitu dengan pelayanan konseling kelompok. Konseling kelompok merupakan suatu proses pemberian bantuan kepada individu melalui suasana kelompok yang memungkinkan individu dapat mengembangkan wawasan dan pemahaman yang diperlukan tentang suatu masalah tertentu, mengeksplorasi, dan menentukan alternatif terbaik untuk mengatasi masalahnya itu atau dalam upaya mengembangkan pribadinya (Sonstegard \& Bitter, 2004; Corey \& Corey, 2005; Berg, Landreth \& Fall, 2006). Melalui pelayanan konseling kelompok, mahasiswa difasilitasi untuk saling pengertian, saling perhatian, dan saling mendukung dalam mengembangkan pemahaman diri, kesadaran diri, penerimaan diri, aktualisasi diri, pencerahan diri, pengentasan masalah, pendidikan psikologis, keterampilan sosial, perubahan kognitif, afektif, psikomotorik, perubahan sistem, penguatan diri, reproduksi ,dan aksi sosial.

Berdasarkan kajian teoretik dan dan fakta empirik tersebut, penelitian ini difokuskan pada pengembangan model konseling kelompok sebagai upaya untuk meningkatkan self-efficacy mahasiswa dalam menyusun skripsi agar selesai tepat waktu dengan kualitas yang baik. Hasil penelitian ini akan direkomendasikan bagi para dosen Penasihat Akademik (PA) dan pembimbing skripsi di Jurusan BK FIP UNJ secara khusus, dan pada batas-batas tertentu dimungkinkan untuk digunakan di Jurusan lain di UNJ. Tujuan penelitian ini adalah mendapatkan model konseling kelompok (hipotetik) yang efektif untuk meningkatkan self-efficacy mahasiswa yang sedang menulis skripsi. Secara khusus, penelitian ini ditujukan untuk mendapatkan gambaran empirik tentang selfefficacy mahasiwa yang sedang menulis skripsi.

\section{METODE PENELITIAN}

\section{Jenis Penelitian}

Penelitian menggunakan metode Research and Development (Borg and Gall, 2003) dengan beberapa modifikasi dan improvisasi dalam prosedurnya. 
Dalam penelitian ini hanya sampai pengembangan model (hipotetik-teoretik) konseling kelompok untuk meningkatkan academic self-efficacy mahasiswa di Jurusan BK FIP UNJ.

\section{Tempat dan Waktu Penelitian}

Penelitian dilaksanakan mulai bulan Maret Desember 2012, dan dilaksanakan di Jurusan BK FIP UNJ.

\section{Prosedur Penelitian}

a. Sumber data

Populasi dalam penelitian ini adalah seluruh mahasiswa Jurusan BK FIP UNJ angkatan 2007 yang sedang menulis skripsi tahun akademik 2011/2012 yang berjumlah 120 orang. Anggota sampel diambil menggunakan teknik simple random sampling. Jumlah anggota sampel ditetapkan $40 \%$ dari seluruh populasi. Dengan demikian, sampel penelitian berjumlah 48 orang.

b. Teknik Pengumpulan Data

Data tentang academic self-efficacy mahasiswa yang sedang menulis skripsi dijaring menggunakan Kuesioner Academic Self-Efficacy Mahasiswa (ASEM) yang dikonstruksi sendiri oleh peneliti berdasarkan konstruk teori self-efficacy dari Bandura (2006). Instrumen tersebut berbentuk skala dengan empat alternatif jawaban yang terdiri atas 20 item yang valid dengan indeks reliabilitas 0,92. Artinya, instrumen tersebut reliabel (Anastasi \& Urbina, 1997) dan dapat digunakan untuk mengungkap academic self-efficacy mahasiswa.

c. Teknik Analisis Data

Teknik analisis data yang digunakan untuk menjawab rumusan masalah penelitian adalah statistik deskriptif berupa persentase. Kategorisasi posisi profil academic self-efficacy mahasiswa, baik secara keseluruhan maupun pada setiap dimensinya (magnitude, strength, generality) dipergunakan rerata ideal dengan kriteria: jika $X_{\text {aktual }}>\bar{X}_{\text {ktual }}$ termasuk kategori tinggi, dan $\mathrm{X}_{\text {aktual }} \leq \bar{X}_{\text {aktual }}$ termasuk kategori rendah $(\mathrm{X}=$ jumlah skor aktual; $\bar{X}=$ Rerata). Analisis data secara keseluruhan dilakukan secara computerized menggunakan bantuan program Microsoft Excel 2007 dan software SPSS 20.0 for Windows. Selanjutnya, untuk penentuan persentase secara keseluruhan, subkompetensi maupun dimensinya digunakan rumus berikut.

$$
\mathrm{P}=\frac{f}{N} \times 100
$$

Pertanyaan penelitian kedua, akan dijawab dengan mengikuti langkah-langkah berikut: (1) mengkaji hasil penelitian tentang model peningkatan self-efficacy mahasiswa yang sedang menulis skripsi sebagai bahan awal analisis kebutuhan; (2) menganalisis kebutuhan program self-efficacy mahasiswa yang sedang menulis skripsi berdasarkan hasil penelitian; (3) mengkaji pendekatan dan strategi bimbingan dan konseling dalam menerapkan model yang dirancang; (4) mengkaji dokumen yang dianggap relevan untuk pengembangan Pedoman Pelaksanaan Model; dan (5) merancang model hipotetik self-efficacy mahasiswa yang sedang menulis skripsi.

\section{HASIL DAN PEMBAHASAN}

\section{Gambaran Self-Efficacy Mahasiswa yang Sedang Menulis Skripsi}

Hasil penelitian menunjukkan bahwa selfefficacy mahasiswa Jurusan BK FIP UNJ yang sedang menulis skripsi angkatan 2009 tahun akademik 2011/2012 berada pada kategori "tinggi" sebesar 52,1\% dan sisanya sebesar 47,9\% "rendah". Jika dianalisis pada setiap dimensi dan indikatornya, maka diperoleh gambaran bahwa terdapat dua dimensi yang berada pada kategori rendah dan satu dimensi yang berada pada kategori tinggi. Pertama, dimensi self-efficacy yang berada pada kategori tinggi adalah strength sebesar 56,3\% dan sisanya "rendah" sebesar 45,7\%. Artinya, mahasiswa memiliki taraf keyakinan terhadap kemampuannya dalam mengatasi masalah atau kesulitan yang muncul akibat tugas-tugas yang berkaitan dengan penulisan skripsi. Tingginya persentase dimensi strength hanya didukung oleh indikator berkomitmen untuk menyelesaikan tugas yang berkaitan dengan penulisan skripsi sebesar 58,3\%, sedangkan indikator meningkatkan upaya sebaik-baiknya untuk menyelesaikan penulisan skripsi berada pada kategori rendah sebesar $(68,8 \%)$.

Kedua, dimensi magnitude berada pada kategori rendah adalah sebesar $100 \%$. Artinya, mahasiswa memiliki taraf keyakinan dan kemampuan yang rendah dalam menentukan tingkat kesulitan tugas atau masalah yang dihadapi dalam menulis skripsi. Rendahnya dimensi magnitude didukung oleh ketiga indikatornya, yaitu berwawasan optimis sebesar 50\%, merencanakan penyelesaian tugas-tugas yang berkaitan dengan skripsi sebesar62,5\% dan merasa yakin mampu menyelesaikan tugas-tugas yang berkaitan dengan penulisan skripsi sebesar 60,4\%.

Ketiga, dimensi generality berada pada kategori rendah 52,1\% dan sisanya tinggi 47,9\%. Artinya, mahasiswa memiliki taraf keyakinan dan kemampuan yang rendah dalam menggeneralisasikan tugas dan pengalaman sebelumnya yang berkaitan dengan penulisan skripsi. Walaupun demikian, jika dilihat pada kedua indikatornya berada pada kategori tinggi, yaitu menyikapi situasi dan kondisi yang beragam dengan cara yang baik dan positif (54,2\%) dan berpedoman 
pada pengalaman hidup sebagai suatu langkah untuk mencapai keberhasilan (54,2\%). Hasil penelitian tervisualisasikan pada grafik 1 dan 2 .

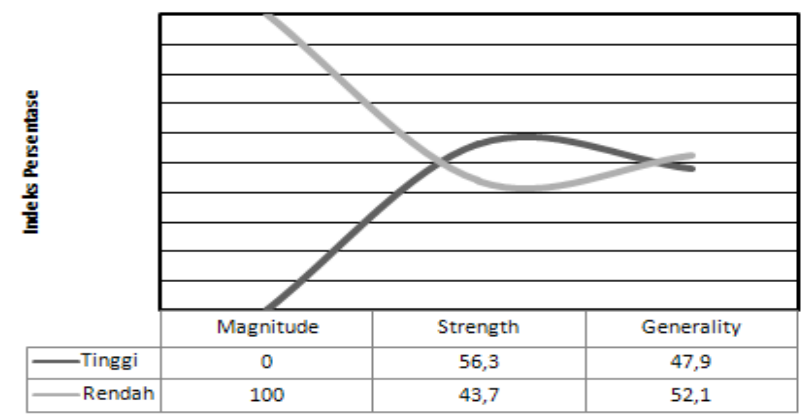

Gambar 1. Grafik Dimensi Academic Self-Efficacy Mahasiswa yang Sedang Menulis Skripsi

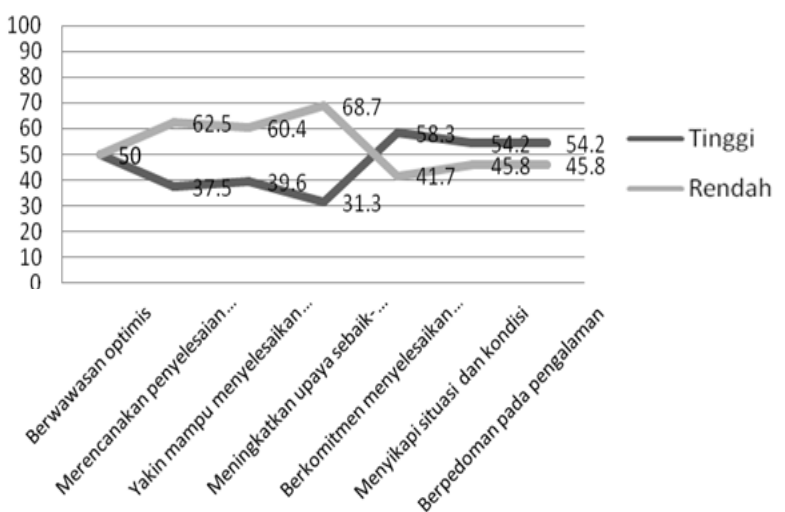

Gambar 2. Grafik Indikator Academic Self-Efficacy Mahasiswa yang Sedang Menulis Skripsi

Hasil penelitian ini juga memperoleh gambaran tentang tingkat keyakinan mahasiswa akan kemampuannya dalam menyelesaikan tugas-tugas yang berkaitan dengan penulisan skripsi. Mahasiswa merasa yakin akan kemampuannya dalam menyelesaikan tugas terkait dengan (1) pemilihan topik yang layak untuk diteliti $(64,6 \%)$, (2) perumusan kerangka berpikir $(68,8 \%)$, (3) pemilihan hasil penelitian terdahulu yang relevan $(66,7 \%)$, (4) penentuan populasi secara tepat $(64,6 \%),(5)$ pemilihan teknik sampling yang tepat $(70,8 \%),(6)$ pengujian kualitas instrumen penelitian $(72,9 \%),(7)$ pemilihan teknik analisis data secara tepat $(64,6 \%),(8)$ penggunaan teknik statistik sederhana $(70,8 \%)$, (9) penginterpretasian data penelitian dari analisis kuantitatif ataupun kualitatif secara efektif $(70,8 \%),(10)$ pembahasan hasil penelitian secara efektif $(66,7 \%)$, (11) perumusan implikasi hasil penelitian (68,8\%); (12) mendapatkan literatur yang memadai (68,8\%), dan (13) pelaksanaan bimbingan skripsi secara intensif dan efektif dengan pembimbing (75\%).

Mahasiswa merasa tidak yakin akan kemampuannya dalam menyelesaikan tugas-tugas yang berkaitan dengan skripsi menyangkut (1) penulisan proposal penelitian $(75 \%)$, (2) mengikuti ujian seminar proposal $(68,7 \%)$, (3) perumusan latar belakang masalah penelitian $(77,1 \%)$, (4) pengidentifikasian masalah penelitian $(72,9 \%)$, (5) perumusan masalah penelitian $(72,9 \%)$, (6) penetapan batasan masalah penelitian $(72,9 \%)$, (7) perumusan tujuan penelitian $(70,8 \%),(8)$ perumusan manfaat penelitian $(70,8 \%)$, (9) penulisan kajian teoretik (72,9\%), (10) perumusan definisi konseptual dan operasional variabel $(79,2 \%)$, (11) penentuan jumlah sampel penelitian secara tepat (70,8\%), (12) pemilihan teknik pengumpulan data secara tepat (75\%), (13) penulisan hasil penelitian (75\%), (14) penulisan hasil penelitian (75\%), (15) penarikan kesimpulan hasil penelitian $(81,2 \%)$, (16) penulisan saran penelitian $(79,2 \%),(17)$ mengikuti seminar hasil penelitian $(62,5 \%)$, (18) mengikuti ujian skripsi $(60,4 \%)$, (19) menyediakan biaya yang diperlukan untuk melaksanakan penelitian $(64,6 \%)$. Hasil penelitian secara rinci disajikan pada tabel 1 .

Tabel 1. Tingkat Keyakinan Mahasiswa Menyelesaikan Tugas-tugas Terkait Skripsi

\begin{tabular}{|c|l|c|c|}
\hline \multirow{2}{*}{ No. } & \multicolumn{2}{|c|}{ Tugas dalam Skripsi } & \multicolumn{2}{c|}{ \% Tingkat Keyakinan } \\
\cline { 2 - 4 } & Mampu .... & Yakin & $\begin{array}{c}\text { Tidak } \\
\text { Yakin }\end{array}$ \\
\hline 1 & $\begin{array}{l}\text { Memilih topik yang layak untuk } \\
\text { diteliti }\end{array}$ & 64.6 & 35.4 \\
\hline 2 & Menulis proposal penelitian & 25 & 75 \\
\hline 3 & Mengikuti ujian seminar proposal & 31.3 & 68.7 \\
\hline 4 & $\begin{array}{l}\text { Merumuskan latar belakang ma- } \\
\text { salah penelitian }\end{array}$ & 22.9 & 77.1 \\
\hline 5 & $\begin{array}{l}\text { Mengidentifikasi masalah pene- } \\
\text { litian }\end{array}$ & 27.1 & 72.9 \\
\hline 6 & Merumuskan masalah penelitian & 27.1 & 72.9 \\
\hline 7 & $\begin{array}{l}\text { Menetapkan batasan masalah } \\
\text { penelitian }\end{array}$ & 27.1 & 72.9 \\
\hline 8 & Merumuskan tujuan penelitian & 29.2 & 70.8 \\
\hline 9 & Merumuskan manfaat penelitian & 29.2 & 70.8 \\
\hline 10 & Menuliskan kajian teoretik & 27.1 & 72.9 \\
\hline 11 & Merumuskan kerangka berpikir & 68.8 & 31.2 \\
\hline 12 & $\begin{array}{l}\text { Memilih hasil penelitian terdahulu } \\
\text { yang relevan }\end{array}$ & 66.7 & 33.3 \\
\hline 13 & $\begin{array}{l}\text { Merumuskan definisi konseptual } \\
\text { dan operasional variabel }\end{array}$ & 20.8 & 79.2 \\
\hline 14 & Menentukan populasi secara tepat & 64.6 & 35.4 \\
\hline 15 & $\begin{array}{l}\text { Menentukan jumlah sampel secara } \\
\text { tepat }\end{array}$ & 29.2 & 70.8 \\
\hline 16 & $\begin{array}{l}\text { Memilih teknik sampling yang } \\
\text { tepat }\end{array}$ & 70.8 & 29.2 \\
\hline 17 & $\begin{array}{l}\text { Pengembangan instrumen peneli- } \\
\text { tian (kisi-kisi, pernyataan) }\end{array}$ & 52.1 & 47.9 \\
\hline 18 & $\begin{array}{l}\text { Pengujian kualitas instrumen (va- } \\
\text { liditas dan reliabilitas atau daya } \\
\text { pengecoh) }\end{array}$ & 72.9 & 27.1 \\
\hline
\end{tabular}

Perspektif Ilmu Pendidikan - Vol. 27 Th. XVIII April 2013 


\begin{tabular}{|c|l|c|c|}
\hline \multirow{2}{*}{ No. } & \multicolumn{1}{|c|}{ Tugas dalam Skripsi } & \multicolumn{2}{c|}{ \% Tingkat Keyakinan } \\
\cline { 2 - 4 } & Mampu .... & Yakin & $\begin{array}{c}\text { Tidak } \\
\text { Yakin }\end{array}$ \\
\hline 19 & $\begin{array}{l}\text { Memilih teknik pengumpulan } \\
\text { data secara tepat }\end{array}$ & 25 & 75 \\
\hline 20 & $\begin{array}{l}\text { Memilih teknik analisis data se- } \\
\text { cara tepat }\end{array}$ & 64.6 & 35.4 \\
\hline 21 & $\begin{array}{l}\text { Menggunakan teknik statistik } \\
\text { sederhana (distribusi frekuensi, } \\
\text { korelasi, } t \text {-test, dan lain-lain.) }\end{array}$ & 64.6 & 35.4 \\
\hline 22 & Menulis hasil penelitian & 25 & 75 \\
\hline 23 & $\begin{array}{l}\text { Menginterpretasikan data hasil } \\
\text { penelitian dari analisis kuantitatif } \\
\text { ataupun kualitatif secara efektif }\end{array}$ & 70.8 & 29.2 \\
\hline 24 & $\begin{array}{l}\text { Membahas hasil penelitian secara } \\
\text { efektif }\end{array}$ & 66.7 & 33.3 \\
\hline 25 & $\begin{array}{l}\text { Menarik kesimpulan hasil pene- } \\
\text { litian }\end{array}$ & 18.8 & 81.2 \\
\hline 26 & $\begin{array}{l}\text { Merumuskan implikasi hasil pene- } \\
\text { litian }\end{array}$ & 68.8 & 31.2 \\
\hline 27 & Merumuskan saran penelitian & 20.8 & 79.2 \\
\hline 28 & $\begin{array}{l}\text { Mendapatkan literatur yang me- } \\
\text { madai (buku, jurnal) }\end{array}$ & 68.8 & 31.2 \\
\hline 30 & Mengikuti seminar hasil penelitian & 37.5 & 62.5 \\
\hline 31 & Mengikuti ujian skripsi & 39.6 & 60.4 \\
\hline 32 & $\begin{array}{l}\text { Menyediakan biaya yang di- } \\
\text { perlukan untuk melaksanakan } \\
\text { penelitian }\end{array}$ & 35.4 & 64.6 \\
\hline
\end{tabular}

Model Konseling Kelompok untuk Meningkatkan Self-Efficacy Mahasiswa yang Sedang Menulis Skripsi

Berdasarkan hasil penelitian tentang gambaran self-efficacy, maka model konseling kelompok yang diprediksi tepat digunakan untuk meningkatkan selfefficacy mahasiswa yang sedangkan menulis adalah konseling kelompok kognitif-perilaku (KKKP). model KKKP untuk meningkatkan self-efficacy mahasiswa yang sedang menulis skripsi terdiri atas: rasional, tujuan, komponen utama, format, sesi dan tahapan kegiatan, peran konselor, indikator keberhasilan.

\section{Rasional}

KKKP merupakan suatu sistem yang kritis untuk setiap individu. Sebagai suatu arena interaksi sosial atau hubungan sosial, kelompok berpotensi untuk memfasilitasi suatu rentang kebutuhan individu. Kelompok berpotensi memfasilitasi individu untuk: (1) memiliki dan diterima; (2) disahkan melalui proses umpan balik; (3) bertukar pengalaman bersama dengan yang lain; (4) kesempatan bekerja dengan orang lain tentang tugas-tugas umum (Anderson \& Carter dalam Supriatna, 2004) dan (5) tujuan terapeutik, pendidikan atau kombinasi keduanya; (6) membuat perubahan yang fundamental dalam aspek pikiran, perasaan dan perilaku dengan berfokus pada mempelajari strategi keterampilan coping secara spesifik
(Corey, 2012).

Pendekatan KKKP digunakan sebagai salah satu model yang diprediksi tepat digunakan untuk meningkatkan self-efficacy mahasiswa yang sedang menulis skripsi adalah karena KKKP memiliki karakteristik utama: (1) menekankan peran dari makna personal yang diberikan pada kejadian dalam menentukan respon emosi; (2) dikembangkan melalui evaluasi ilmiah yang terfokus dan dilakukan terus menerus; (3) berfokus lebih kepada bagaimana permasalahan individu bisa terus bertahan atau melekat pada dirinya, dan bukannya mencari akar penyebab dari munculnya permasalahan; (4) menawarkan konseling praktis dan alat untuk menghadapi masalah emosi yang seringkali muncul; (5) memegang teguh cara pandang bahwa individu dapat mengubah dan mengembangkan diri dengan cara berpikir dan mencoba ide dan strategi baru; (6) dapat membahas materi dari masa lalu individu bila dengan cara itu dapat membantunya memahami dan mengubah cara berpikir dan bertindak saat ini; (7) menunjukkan kepada individu bahwa beberapa strategi yang digunakan untuk mengatasi masalah emosi sebenarnya justru membuat permasalahan tetap ada; (8) berusaha keras untuk membuat emosi individu normal kembali, sensasi fisik, pikiran dan bukan menginformasikan kepada individu bahwa KKKP adalah petunjuk dari permasalahan yang tersembunyi; (9) mengenali bahwa individu dapat mengembangkan masalah emosi tentang permasalahan emosional; dan (10) menggarisbawahi teknik pembelajaran dan memaksimalkan upaya membantu diri sendiri (self help) sehingga betul-betul dapat menjadi konselor/ terapis bagi diri sendiri (Willson \& Branch, 2006); (11) kebanyakan perilaku manusia dipelajari dan karena itu dapat diubah; (12) perubahan-perubahan khusus terhadap lingkungan individual dapat membantu dalam mengubah perilaku-perilaku yang relevan; (13) prinsip-prinsip belajar sosial, seperti "reinforcement" dan "social learning" dapat digunakan untuk mengembangkan prosedur-prosedur konseling; dan (14) prosedur-prosedur konseling tidak statik, tetap atau ditentukan sebelumnya, tetapi dapat secara khusus dirancang untuk membantu konseli dalam mengatasi masalah khusus (Thoresen dalam Shertzer \& Stone, 1980).

\section{Tujuan}

Tujuan umum KKKP adalah meningkatkan self-efficacy mahasiswa yang sedang menulis skripsi. Tujuan khusus KKKP adalah meningkatkan: (1) taraf keyakinan terhadap kemampuannya dalam mengatasi masalah atau kesulitan yang muncul akibat tugastugas yang berkaitan dengan penulisan skripsi; (2) 
taraf keyakinan dan kemampuan yang rendah dalam menentukan tingkat kesulitan tugas atau masalah yang dihadapi dalam menulis skripsi; (3) taraf keyakinan dan kemampuan yang rendah dalam menggeneralisasikan tugas dan pengalaman sebelumnya yang berkaitan dengan penulisan skripsi; (4) mengembangkan metode khusus untuk mengendalikan diri; (5) pemantauan diri (self-monitoring) mengenai perilaku atau kognisinya sendiri sebagai jalan untuk mendatangkan perubahan; (6) belajar memberikan dan menerima balikan yang positif dan negatif; (7) mampu mengenal dan menantang pola pikir yang merusakkan diri sendiri atau pernyataan diri yang irrasional; (8) belajar tentang keterampilan sosial dan keterampilan berkomunikasi; dan (9) mengembangkan strategi mengatasi masalah dalam berbagai situasi yang dihadapi dalam kehidupan.

\section{Komponen Utama}

KKKP untuk meningkatkan self-efficacy mahasiswa yang sedang menulis skripsi dirancang dalam dua komponen utama, yaitu analisis fungsional dan pelatihan keterampilan. Pertama, selama proses konseling, konselor dan konseli melakukan analisis fungsional, yaitu mengidentifikasi pemikiran, perasaan, dan lingkungan konseli yang dapat mendukung atau menghambatnya dalam penulisan skripsi. Pada awal konseling, analisis fungsional memerankan peranan kritis dalam membantu konseli dan konselor untuk menguji faktor-faktor penentu, atau situasi dengan risiko tinggi dan memberikan cara pandang yang berbeda. Kedua, pelatihan keterampilan yaitu melupakan dan mengeliminasi kebiasaan lama yang negatif dan maladaptif dan mempelajari keterampilan baru yang lebih positif, produktif, efektif dan adaptif. Pada saat kegiatan pelatihan keterampilan juga disertai tugas yang harus dikerjakan oleh konseli. Tugas-tugas kritis tersebut sangat membantu konseli karena: (1) mengajarkan keterampilan, (2) kemungkinan mengubah cara pemberian bantuan, (3) mengelola akibat dari suatu keputusan dan tindakan, dan (4) meningkatkan fungsi interpersonal dan dukungan sosial. Selain itu, faktor lain yang turut dipertimbangkan dan didiskusikan adalah sumber-sumber yang mempengaruhi selfefficacy, yaitu: pengalaman keberhasilan, pengalaman vicarious, persuasi verbal, dan kondisi fisiologis dan emosi konseli.

\section{Format, Sesi, Tahapan dan Peran Konselor}

Format dan sesi KKKP dibuat terstruktur, terpola, didaktik dan berorientasi pada pembelajaran. Walaupun proses konseling dilaksanakan dalam setting kelompok tetapi tetap memperhatikan perkembangan dan permasalahan konseli secara individual.
Karena itu, konselor KKKP mengambil sikap yang lebih aktif dan direktif dalam melaksanakan berbagai bentuk konseling. Selama proses konseling dalam masing-masing sesi, konselor meninjau kembali (1) latihan-latihan praktik; (2) masalah-masalah yang mungkin terjadi dalam setiap sesi sampai sesi terakhir; (3) pelatihan keterampilan; (4) umpan balik terhadap pelatihan keterampilan; (5) praktik di dalam sesi; dan (6) perencanaan untuk minggu berikutnya. Sikap aktif ini harus disesuaikan dengan waktu untuk memahami dan berkomunikasi dengan konseli.

Selama melaksanakan KKKP, konselor mengikuti "Peraturan 20/20/20" yang dibuat untuk mencapai integrasi yang baik antara materi dalam manual (manual-driven) dan dorongan konseli (counselee-driven) dalam setiap sesi, dalam sesi KKKP selama 60 menit. Pada 20 menit pertama, konselor memusatkan pada cara memperoleh pemahaman yang jelas tentang kepedulian konseli saat ini, fungsi umum self-efficacy, pemahaman mengenai praktik latihan keahlian. Sesi ini cenderung lebih terkarakterisasikan oleh konseli yang lebih banyak berbicara, walaupun konselor membimbing dengan pertanyaan dan refleksi yang pada gilirannya diperoleh pengertian tentang status terbaru konseli. 20 menit kedua diperuntukan bagi perkenalan dan diskusi keterampilan tertentu. Konselor berbicara lebih banyak daripada konseli selama sesi. Konselor membuat materi-materi didaktik sesuai selera sendiri (teori yang dipilihnya) dan memeriksa konseli untuk memastikan bahwa dia telah dapat mencontoh dan memahami materi yang telah diberikan. 20 menit terakhir, konseli yang lebih banyak mendominasi. Konseli dan konselor membuat kesepatakan untuk mengadakan praktik-praktik latihan di minggu depan serta merencanakan dan mengantisipasi setiap kesulitan yang mungkin dihadapi oleh konseli sebelum sesi selanjutnya. Secara keseluruhan sesi yang ditawarkan adalah 8-12 sesi.

Berdasarkan hasil kajian terhadap berbagai pendapat ahli seperti Natawidjaja (1987), Supriatna (2004), Corey (2005), Corey (2012) dapat disimpulkan bahwa intervensi konseling kelompok, termasuk KKKP dilakukan dengan menempuh 4 (empat) langkah, yaitu: (1) pembentukkan/pembukaan kelompok, (2) penanganan (tahap inti), (3) penutupan, dan (4) tindak lanjut. Pertama, tahap pembukaan merupakan tahap yang paling kritical, artinya keberhasilan pada tahap pembukaan akan menentukan tahap penanganan dan tahap penutupan kelompok, bahkan akan menentukan tercapai tidaknya tujuan bimbingan kelompok. Tahap pembukaan merupakan tahap penciptaan suasana kelompok yang kondusif bagi para 
anggota, yang tujuan intinya adalah para anggota melibatkan diri secara aktif dalam proses kelompok. Pada tahap ini konselor perlu menggunakan teknikteknik membuka komunikasi yang baik dan teknik memperkenalkan anggota yang memungkinkan dapat mencairkan kebekuan suasana kelompok. Suasana hangat, terbuka, dan bebas untuk setiap anggota dalam mengungkapkan dirinya merupakan indikator keberhasilan yang amat penting. Kadang-kadang tahap ini baru bisa dicapai setelah dua sesi pertemuan. Tergantung pada karakteristik dan dinamika interaksi para anggota kelompok yang bersangkutan.

Kedua, tahap penanganan (working) merupakan tahap inti atau tahap kegiatan inti karena langsung berkaitan dengan upaya pencapaian tujuan yang telah ditetapkan pada tahap pembukaan. Tahap ini konselor harus berperan sebagai pengatur pembicaraan anggota, sabar, aktif tapi tidak banyak bicara, memberikan dorongan dan penguatan serta empati. Tugas konselor KKKP pada tahap penanganan, di antaranya : (1) penguatan kembali; (2) kontrak kontingensi; (3) pemberian contoh; (4) gladi perilaku (behavioral rehearsal); (5) melatih (coaching); (6) penataan kembali kognisi (cognitive restructuring); (7) pemecahan masalah; (8) mengajarkan teknik-teknik keterampilan untuk mengatasi keadaan (coping-skills techniques); dan (8) pembentukan sistem teman dekat (buddy system) (Natawidjaja, 1987). Tahap inti ini biasanya dilakukan dalam beberapa sesi pertemuan. Setiap sesi pertemuan dilaksanakan sesuai dengan jadwal waktu dan tempat yang disepakati bersama. Untuk kasus atau masalah tertentu, anggota diberi kegiatan yang harus dilakukan di luar kelompok kemudian melaporkannya di dalam kelompok. Indikator keberhasilan tahap ini adalah pemahaman yang baik dari setiap anggota tentang masalah/topik tertentu. Indikator utama keberhasilan tahap inti adalah tuntasnya pemecahan masalah yang dihadapi oleh anggota tertentu atau setiap anggota.

Ketiga dan keempat, penutupan dan tindak lanjut. Jika pemahaman atau ketuntasan pemecahan masalah sudah dicapai, maka tahap penutupan harus dilakukan. Indikator utama keberhasilan tahap ini adalah para anggota mengungkapkan perubahan tingkah laku (pemahaman atau ketuntasan) yang dicapai dan memberi isyarat verbal atau non-verbal yang mengindikasikan kegiatan harus ditindaklanjuti atau munculnya keinginan dan harapan baru.

\section{Pembahasan Hasil Penelitian}

Hasil penelitian menunjukkan bahwa mahasiswa yang sedang menulis skripsi memiliki perbedaan tingkat self-efficacy yang sangat tipis. Dengan kata lain, tingkat self-efficacy mahasiswa yang tinggi dan rendah memiliki persentase yang hampir seimbang. Mahasiswa yang self-efficacy-nya tinggi didukung oleh tingginya persentase dimensi strength. Artinya, mahasiswa memiliki taraf keyakinan terhadap kemampuannya dalam mengatasi masalah atau kesulitan yang muncul akibat tugas-tugas yang berkaitan dengan penulisan skripsi. Tingginya persentase dimensi strength hanya didukung oleh indikator berkomitmen untuk menyelesaikan tugas yang berkaitan dengan penulisan skripsi. Sementara itu, mahasiswa yang self-efficacy-nya rendah didukung oleh rendahnya persentase dimensi magnitude dan generality. Pada dimensi magnitude, seluruh mahasiswa yang sedang menulis skripsi berada pada kategori rendah. Artinya, mahasiswa memiliki taraf keyakinan dan kemampuan yang rendah dalam menentukan tingkat kesulitan tugas atau masalah yang dihadapi dalam menulis skripsi. Rendahnya persentase magnitude mahasiswa ditandai oleh berwawasan pesimis, belum mampu merencanakan penyelesaian tugas-tugas yang berkaitan dengan skripsi, dan tidak yakin mampu menyelesaikan tugas-tugas yang berkaitan dengan penulisan skripsi. Mahasiswa juga rendah dalam dimensi generality. Artinya, mahasiswa memiliki taraf keyakinan dan kemampuan yang rendah dalam menggeneralisasikan tugas dan pengalaman sebelumnya yang berkaitan dengan penulisan skripsi.

Menurut Bandura (Maddux, 2005; Sudrajat, 2008) self-efficacy yang tinggi akan berimplikasi pada tiga hal, yaitu: (1) penetapan tujuan yang dibuat akan berkembang menjadi domain tujuan prestatif, pemilihan berbagai aktivitas secara selektif dan efektif dalam rangka mencapai tujuan, misalnya memilih usaha-usaha yang dilakukan, dan tekun bila dihadapkan pada sejumlah tantangan dan rintangan dan menyelaraskan antara reaksi pertentangan tujuan dan prestasi saat ini; (2) akan resisten terhadap gangguan atau hambatan, dan menunjukkan perilaku tekun yang mengarahkan pada kesuksesan; dan (3) dapat mengatasi masalah secara efektif sehingga dapat membuat keputusan. Dalam menghadapi kesulitan, individu yang self-efficacy-nya tinggi akan mendiagnosis tugas dan mencari solusi atas masalah yang dihadapinya. Jika self-efficacy-nya rendah, mungkin ia akan bertindak sebaliknya.

Self-efficacy mempengaruhi perancangan dan pencapaian tujuan individu. Semakin mampu individu meyakini kemampuan dirinya, maka semakin tinggi tujuan yang akan dirancang untuk dirinya, dan akan semakin berkomitmen dengan tujuan-tujuan yang sudah dirancang tersebut (Bandura, 1986; Locke \& Latham, 1990). Individu yang memiliki self-efficacy 
tinggi akan meningkatkan usahanya dalam mencapai tujuan, sementara individu yang self-efficacy-nya rendah, akan menyerah dan keluar dari usahanya (Bandura, 1986). Tujuan dapat mempengaruhi keyakinan tentang self-efficacy dan sebaliknya.

Pendapat dan hasil penelitian sebelumnya juga memperkuat bahwa self-efficacy mempengaruhi prestasi akademik individu. Self-efficacy yang tinggi akan mempengaruhi usaha dan memperkaya energi individu dalam beraktivitas atau belajar seperti menjadi solusi atas masalah-masalah aritmatika, memperkuat persistensi motivasi dan prestasi akademik (Zimmerman, 2000). Individu dengan self-efficacy yang tinggi akan membantunya dalam mengelola tugastugas akademik dan pada akahirnya dapat mempengaruhi kondisi emosinya, seperti stress, kecemasan dan depresi (Bandura, 1997). Pajares dan Kranzler (1995) dalam penelitiannya menemukan hubungan antara self-efficacy dan reaksi kecemasan dalam menyelesaikan tugas-tugas matematika. Individu yang self-efficacy-nya tinggi akan mampu menghadapi dan mengatasi kecemasan, begitupun sebaliknya.

Variasi tinggi dan rendahnya tingkat self-efficacy mahasiswa yang sedang menulis skripsi tidak lepas dari berbagai faktor yang mempengaruhi. Menurut Bandura (1977; 1997) self-efficacy secara kontinu turut berkembang sepanjang hayat serta mengintegrasikan informasi dari empat sumber utama berikut.

Pertama, pengalaman keberhasilan. Persepsi tentang keberhasilan atau kegagalan atas sesuatu pada umumnya akan melemahkan atau meningkatkan selfefficacy individu. Semakin sering individu mengalami keberhasilan dalam hidupnya maka semakin tinggi taraf self-efficacy-nya. Sebaliknya, semakin sering individu mengalami kegagalan, maka semakin rendah taraf self-efficacy-nya.

Kedua, pengalaman vicarious. Pengalaman vicarious dapat berupa mengobservasi, meniru, berimajinasi, atau melalui media lainnya.

Ketiga, persuasi verbal. Self-efficacy individu dipengaruhi oleh perkataan orang lain tentang dirinya bahwa ia dapat mengerjakan sesuatu atau tidak. Potensi persuasi verbal sebagai suatu sumber self-efficacy dipengaruhi oleh faktor kemahiran, kepercayaan, dan daya tarik sumber.

Keempat, kondisi fisiologis dan emosi. Keadaan fisik dan emosional berpengaruh terhadap self-efficacy. Keberhasilan atau kegagalan pada umumnya akan memunculkan reaksi fisiologis, baik yang menyenangkan maupun tidak menyenangkan. Jika individu mengalami sesuatu yang tidak menyenangkan, maka akan berpengaruh terhadap dirinya, seperti meragu- kan kemampuannya dalam menyelesaikan sesuatu dibandingkan dengan kemunculan reaksi fisiologis yang netral atau menyenangkannya.

\section{Implikasi}

Self-efficacy memainkan peranan yang penting dalam mencapai kesuksesan akademik mahasiswa, termasuk mahasiswa yang sedang menulis skripsi. Self-efficacy yang tinggi diprediksi dapat membantu mahasiswa dalam menetapkan tujuan dan meyakini akan potensinya untuk mencapai tujuan tersebut, resisten terhadap hambatan dalam menye-lesaikan skripsi, tekun dalam menyelesaikan skripsi dan mampu mengatasi berbagai masalah dalam menyelesaikan skripsi. Sebaliknya, jika self-efficacy rendah diprediksi dapat mengakibatkan mahasiswa kesulitan menetapkan tujuan, pesimis terhadap kemampuannya dalam menyelesaikan skripsi, mudah putus asa, dan tidak dapat menyelesaikan skripsi. Jika mahasiswa terlambat menyelesaikan skripsi apalagi melebihi dua semester, maka tidak hanya merugikan mahasiswa yang bersangkutan saja, tetapi juga merugikan dosen pembimbing dan pihak pimpinan Jurusan BK, bahkan Fakultas dan Universitas.

\section{PENUTUP}

\section{Kesimpulan}

Hasil penelitian terdiri atas gambaran selfefficacy mahasiswa yang sedang menulis skripsi dan model konseling kelompok untuk meningkatkan self-efficacy mahasiswa yang sedang menulis skripsi. Pertama, mahasiswa Jurusan BK FIP UNJ 2007 yang sedang menulis skripsi memiliki self-efficacy yang "tinggi" sebesar 52.1\% dan sisanya rendah $47.9 \%$.jika dianalisis pada setiap dimensi self-efficacy diketahui: (1) magnitude sebesar 100\% rendah; (2) strength berada pada kategori "tinggi" sebesar $56.3 \%$ dan sisanya sebesar 43.7\% "rendah"; dan (3) generality berada pada kategori "rendah" sebesar $52.1 \%$ dan sisanya "tinggi" sebesar $47.9 \%$.

Kedua, model konseling kelompok yang diprediksi efektif untuk meningkatkan self-efficacy adalah konseling kelompok kognitif-perilaku (KKKP). model KKKP dipandang efektif karena sesuai dengan permasalahan self-efficacy, menawarkan teknik yang spesifik dan teruji secara empirik, waktu yang dibutuhkan relatif singkat, serta menggunakan prinsip-prinsip belajar seperti reinforcement dan social learning yang dapat mengembangkan self-help. Model KKKP yang dihasilkan dari penelitian ini terdiri atas: rasional, tujuan, komponen utama, format, sesi, peran konselor, tahapan konseling, dan indikator keberhasilan. 


\section{Saran}

Berdasarkan hasil penelitian, maka peneliti mengemukakan saran yang dapat bermanfaat bagi berbagai pihak terkait.

Bagi Jurusan BK FIP UNJ diharapkan dapat mempertimbangkan dan memasukkan isu-isu selfefficacy, khususnya self-efficacy ke dalam perkuliahan, khususnya pada mata kuliah teori kepribadian, kesehatan mental dan BK Pribadi sehingga berdampak langsung maupun tidak langsung pada meningkatknya self-efficacy mahasiswa. Selain itu, pihak Jurusan BK FIP UNJ dapat mempertimbangkan model KKKP untuk meningkatkan self-efficacy mahasiswa yang sedang menulis skripsi agar mahasiswa tidak terlambat dalam menyelesaikan skripsi. Khusus bagi dosen mata kuliah statistik dan metodologi penelitian diharapkan dapat mengubah persepsi mahasiswa tentang meneliti itu sulit dan meningkatkan kesadaran pentingnya penelitian.

Mahasiswa Jurusan BK FIP UNJ yang sedang menulis skripsi diharapkan secara berkelanjutan meningkatkan self-efficacy melalui pendayagunaan sumber-sumber yang mempengaruhi self-efficacy, yaitu pengalaman keberhasilan, pengalaman vicarious, persuasi verbal dari orang lain menjaga kondisi fisiologis dan emosi. Selain itu, mahasiswa dapat mengikuti kegiatan pelatihan dan konseling KKKP atau kegiatan sejenis yang dapat meningkatkan self-efficacy dalam menulis skripsi.

Peneliti selanjutnya yang berminat dengan tema penelitian self-efficacy dapat mengkaji variabel-variabel lain yang terkait seperti: faktor-faktor atau sumbersumber yang mempengaruhi self-efficacy, dan menguji efektivitas model KKKP atau model lainnya yang efektif untuk meningkatkan self-efficacy mahasiswa yang sedang menulis skripsi.

\section{DAFTAR PUSTAKA}

Anastasi, A., \& Urbiana, U. (1997). Psycological testing $\left(7^{\text {th }}, E d\right)$. New Jersey: Prentice-Hall, Inc.

Bandura, A. (1986). Social foundations of thought and action: A social cognitive theory. Englewood Cliffs, New Jersey: Prentice Hall.

Bandura, A. (1977). Self-efficacy: Toward a unifying theory of behavioral change. Psychological Review, 84(2), 191-215.

Bandura, A. (1997). Self-efficacy: The exercise of control. New York: W.H. Freeman and Company.

Bandura, A. (2006). Guide for constructing self-efficacy scales. USA: Age Publising.

Berg, R.C., Landreth, G.L.,\& Fall, K.A. (2006). Group counseling. USA: Taylor \& Francis Group Inc.

Borg, W.R.,\& Gall, M.D. (2003). Educational reseach: An introduction. London: Longman, Inc.

Corey, G.,\& Corey, M.S. (2005). Groups: process and practice (7th edition). USA: Thomson \& Brooks/ Cole Publishing Company. .

Natawidjaja, R. (1987). Penyuluhan kelompok. Bandung: Jurusan PPB FIP UPI.

Pajares, F.,\& Kranzler, J. (1995). Self-efficacy beliefs and general mental ability in mathematical problemsolving. Contemporary Educational Psychology, 20, 426-443.

Shertzer, B.,\& Stone, S. C. (1980). Fundamentals of guidance. Boston: Houghton Mifflin Company.

Sonstegard, M.A.,\& Bitter, J.R. (2004). Adlerian group counseling $\mathcal{E}$ therapy: Step by step. USA: Taylor and Francis, Inc.

Wilson R.,\& Branch R. (2006) Cognitive behavioural therapy for dummies. London: John Wiley.

Zimmerman, J.B. (2000). Self-efficacy: An essential motive to learn. Contemporary Educational Psychology, 25, 82-91, (2000) doi:10.1006/ceps.1999.1016, available online at http://www.idealibrary.com on [1 Februari 2012].

Zimmerman, B. J.,\& Kitsantas, A. (1996). Self-regulated learning of a motoric skill: The role of goal setting and self-monitoring. Journal of Applied Sport Psychology, 8, 60-75. 